\title{
The perceived moral reprehensibility of strategic mortgage default
}

\author{
Michael J. Seiler \\ The College of William \& Mary, Raymond A. Mason School of Business, Department of Finance, P.0. Box 8795, Williamsburg, VA \\ 23187-8795, United States
}

\section{A R T I C L E I N F O}

\section{Article history:}

Received 16 March 2015

Revised 3 January 2016

Accepted 12 March 2016

Available online 23 March 2016

\section{JEL classification:}

D10

D81

K11

R20

Keywords:

Strategic mortgage default

Other-regarding behavior

Money illusion

Morality

Distressed loan settlement offers

\begin{abstract}
A B S T R A C T
Defaulting on a mortgage is widely viewed as being immoral, but no prior study has examined the intervening roles of financial outcome and default intent. We find that the public is significantly more accepting of a defaulting borrower who earns a zero or negative return on his investment than one who earns a positive return. This moral viewpoint changes significantly when the default is strategic in nature. Defaulters are judged significantly less harshly by those who more so blame the lender for the current financial crisis, those who have previously strategically defaulted, and males. When asked to suggest a "morally appropriate" settlement offer to lenders to resolve the distressed debt, beyond the financial outcome and default intent remaining significant, we further find that those who more so blame the lender, those who view their home as more of an investment rather than a consumption good, those who have previously strategically defaulted, those with lower income levels, and minorities suggest significantly lower settlement offers.
\end{abstract}

(c) 2016 Elsevier Inc. All rights reserved.

\section{Introduction}

Strategic mortgage default is defined as the unwillingness to continue making mortgage payments even though the borrower has the financial means available. This differs from a Non-Strategic Default in which the borrower is simply unable to afford to continue making mortgage payments. Pundits estimate that the percentage of all mortgage defaults that are strategic in nature range from $10 \%$ to 26\% (Guiso et al., 2013; FICO, 2011; Wyman, 2010), a sizable portion of the mortgage market. While impossible to measure with certainty, the occurrence of strategic mortgage default is widely viewed as a major economic contributor to the prolonged economic recovery process that continues to be a drag on the economy.

E-mail address: Michael.Seiler@mason.wm.edu
Borrowers who strategically default can expect the posturing/negotiation process to be protracted over several years and accumulate untold costs in terms of legal expenses, time, and even the creation and prolonging of chronic health problems (Engelberg and Parsons, 2016; Seiler, 2014a). Still, the incentive to live "rent free" in the meantime, and possibly reach a very favorable settlement ${ }^{1}$

\footnotetext{
${ }^{1}$ Although the outcomes are quite uncertain and highly variable from case to case, many of these negotiations with the lender end in a no fault agreement where the borrower relinquishes physical possession of the property in exchange for the lender releasing the deficiency judgment. It is even commonly negotiated that no 1099 be issued to the defaulting borrower. A 1099 would represent "forgiven debt" that the borrower would then have to report as income when filing that year's taxes. For more details on tax ramifications surrounding forgiven debt, see the multiyear moratoria on taxation of discharged debt income from foreclosure actions that congress put into effect through 2013. Laws like these may well have increased strategic defaulting by lowering the cost of default to the borrower.
} 
with an understaffed, undertrained lender legal department who is often loathe to throw good money after bad chasing down borrowers in differentially borrower-friendly states who may or may not have the means to pay awarded deficiency claims (or who reserve the right to file bankruptcy as a last stop effort to prevent an otherwise righteous foreclosure) makes strategic mortgage default a potentially attractive put option for many borrowers to consider exercising.

The act of strategic mortgage default is widely viewed as being immoral even among those who do it (Guiso et al., 2013; Mae, 2010). That $80-90 \%$ of the public believes strategic mortgage default to be immoral tells only part of the story. Are there any mitigating factors the public would consider before judging the actions of borrowers in this high-stakes gamble? In this study, we look towards the social preferences literature to recognize that "otherregarding behavior" (i.e., behavior supporting existing social norms of fairness and equity, but that may lack financial incentives) matters in a strategic mortgage default setting. Specifically, we examine the perceived moral reprehensibility of other homeowners when a defaulting borrower earns a net positive return on his housing investment. $^{2}$ We then differentiate between strategic and Non-Strategic Defaults.

We find that the public does not differentially object when a defaulting borrower settles his case with the lender in a way that leaves him in the overall loss position vs. breaking-even on his investment in the home. However, when a default leads to a settlement that places the homeowner in an overall gain position (i.e., provides a positive return on his overall investment in the home), people view the settlement as being significantly less moral. When defaults are parsed by strategic vs. non-strategic intent, the public significantly finds more moral culpability with a strategically defaulting borrower. And when the strategic defaulter negotiates a settlement allowing for a positive return on his investment, the greatest level of immorality is reported. In addition to our two main treatment effects (financial outcome and default intent) being statistically significant, we further find that those who blame lenders more so than borrowers for the financial crisis, those who have strategically defaulted in the past, and males are significantly more forgiving of mortgage defaulters.

We then ask people to convey what would constitute a "morally appropriate" payoff amount to offer when settling a mortgage debt with the lender under our nine alternative treatments. We confirm our earlier finding by learning that strategic defaulters should pay the most and that, as a group, defaulters should end up in an overall loss position (i.e., they should earn a negative return on their investment). In addition to our main treatment effects once again being statistically significant, we find that those who more so blame lenders for the crisis, those who view a home as more of an investment (as opposed to a consumption good), those who have strategically defaulted in the

\footnotetext{
2 We recognize the virtual impossibility of calculating the return from strategic mortgage default, and for this reason, intentionally provide only a summary return region to sample participants.
}

past, those with lower incomes, and minorities all suggest significantly lower "morally appropriate" settlement offers.

\section{Literature review}

Ruthless default, where the borrower is argued to optimally exercise his put option after experiencing negative equity, has been studied for years. Until recently, however, home prices fell below outstanding loan balances so seldom, that empirical data were more local in nature. During the financial crisis homes have fallen so far and fast on a national scale that it is estimated that roughly $25 \%$ of U.S. homeowners are underwater on their mortgages (RealtyTrac, 2014). Despite this fact, default rates are nowhere near 25\%. As Guiso et al. (2013) and Seiler et al. (2012) explain, there are several reasons borrowers remain current on underwater mortgages. ${ }^{3}$

At the same time, Seiler (2015a) explains that the legal environment surrounding the resolution of mortgage defaults has become so convoluted, due to a myriad of fraudulent activities on the part of the lending industry, ${ }^{4}$ that strategic mortgage defaults are actually being financially incentivized. Wheaton et al. (2015) argue that strategic defaults are performing a necessary service by imposing discipline on a lending system that has run amuck. Others demonize strategic defaulters arguing that legal gamesmanship on the part of borrowers is eroding neighboring home values while footing taxpayers with the bill. ${ }^{5}$ No matter the position taken, a few would deny the importance of the strategic mortgage default issue as it relates to the recovery of our slumping economy.

\section{Experimental design}

Other-regarding behavior describes the idea that as part of a social network, people experience utility beyond the simple maximization of personal wealth (see Cooper and Kagel, 2013 for an extensive summary of this literature). Individuals also have a social preference for fairness and reciprocity. These ideas are illustrated in such experiments as the ultimatum and dictator games. Both these games lead one to conclude that people care about social norms of fairness and reciprocity. Specifically, they will reward people for good behavior and penalize others for bad behavior. Some refer to this preference as reflecting Inequity Aversion. Blount (1995) takes the discussion even further by finding that intentions (beyond pure behavior) matter as well. Her study is particularly relevant to the current investigation as we specifically measure the perceived moral reprehensibility by homeowners of a borrower's strategic mortgage default.

\footnotetext{
${ }^{3}$ It is beyond the scope of the current investigation to report and elaborate on all the economic and behavioral reasons why one would or would not strategically default. For a further discussion, see Seiler (2016a).

4 http://www.post-gazette.com/business/2014/05/25/Mortgage-fraudassault-a-Pyrrhic-victory/stories/201405250140 (accessed 03.01.16)

5 See studies by Gangel et al. (2013), Seiler et al. (2013); Harding et al. (2009), Lin et al. (2009), Rogers and Winter (2009), and Immergluck and Smith (2006) on the well-documented foreclosure contagion, or neighborhood spillover effects, caused by mortgage defaults.
} 
Before describing our experimental design, a discussion of money illusion - the tendency for people to think in nominal prices instead of more relevant real prices - is in order. ${ }^{6}$ By way of example, if a buyer paid $\$ 100,000$ for a home 10 years ago, and a poor market makes the price subsequently fall to $\$ 95,000$, a buyer who wants to sell will irrationally reject an offer for $\$ 99,000$ because it represents a "loss" in his mind that he is not emotionally ready to accept. The financially rational action would be to sell because the offer is $\$ 4000$ above fair market value. Still, the homeowner would rather wait (sometimes even many years) for an offer price that is greater than or equal to his original purchase price of $\$ 100,000$. If the market recovers to the point where in 15 years, the true market value of the home is $\$ 105,000$, and the homeowner receives an offer of $\$ 101,000$, the buyer is more willing to accept the $\$ 101,000$ because it places him in a (nominal) "gain" position.

From a financial standpoint, the homeowner should be reluctant to accept this $\$ 101,000$ offer because it is $\$ 4000$ below market value. The combining of a false reference point (the $\$ 100,000$ purchase price) with ending in the loss domain explains why a buyer would completely ignore current market conditions as well as the time value of money and be more willing to accept this offer over the (nominal) "loss" position scenario.

We begin with the hypothesis that the public will more strongly object on moral grounds to a borrower who defaulted and made a positive return on his "investment in the home" vs. a defaulting borrower who ended in a loss position (or who broke-even). Even though both situations may represent an economic loss in real terms, we know from the extant literature that people suffer from money illusion. To this end, we are careful to write our scenarios within the experiment without reference to either real or nominal terms. With this is mind, we create three variants of the experiment. The first involves the borrower ending in a loss position; the second reflects him breaking even on the overall investment, while the third represents him ending in a gain position.

Then, recognizing the contentious debate surrounding the morality of strategic mortgage default, we further hypothesize that default intent matters in the mind of the public. To measure the effect of this intervening variable, we create three more experimental design variants. The first is where we provide no mention of the default intent and use this as a base-line measure of reaction. In the second, we describe a strategic default, while in the third, we describe a Non-Strategic Default. Below is the exact script we use to describe the first of nine variants in our study.

"A couple bought a home a while back. ${ }^{7}$ At some point, they stopped making their monthly mortgage payments, but remained living in the home.

\footnotetext{
6 See Ackert et al. (2011) and Seiler (2014c) for a more detailed discussion of homeowner money illusion.

7 We are careful to omit the purchase price of the home stemming from concerns that participants of a higher or lower income or wealth level may view these amounts differentially. To control for this consideration, we include income and wealth as explanatory variables in subsequent regressions.
}

Taking into consideration all the financial factors (falling home prices, missed mortgage payments, "rentfree" living, late fees and interest, and so forth) the lender proposed the couple give back the house $A N D$ pay the lender $\$ 80,000$ to "equitably" settle the loan. While this amount represents a "fair settlement," offer in overall financial terms, for the couple to "break-even" on their overall investment, they would need to pay the lender only $\$ 40,000$.

The couple made a counter-offer to give back the house BUT pay the lender only $\$ 60,000$ to settle the loan.

Please rate the morality of the couple's counter-offer to give back the house AND pay the lender $\$ 60,000$, resulting in an overall loss of $-\$ 20,000(\$ 40,000-60,000)$ on the investment on a scale from 1 to $8(1=$ immoral$8=$ moral)"

Note that the second sentence describes the "no reason given for default" treatment. The first sentence as well as the entire second paragraph are the same for all nine variants and are written to establish what would constitute a "fair settlement" and the break-even (or reference) point for the borrower. ${ }^{8}$ Because of the previously established financial irrationality of money illusion, we are intentionally vague in the wording of the scenarios (relating to the timing and amounts spent) to disallow participants the ability to attempt their own calculations. Instead, we summarize everything for them allowing for the ceteris paribus examination we seek to achieve. ${ }^{9}$

For reporting purposes, the Strategic Default wording used in the second sentence of the scenario reads, "The couple could afford to continue making their monthly mortgage payments, but believed it was no longer in their best financial interests. At some point, they stopped making payments, but remained living in the home". The NonStrategic Default scenario has the second sentence read, "After a series of financial setbacks brought on by an unexpected major illness, ${ }^{10}$ the couple was no longer able to continue making their monthly mortgage payments. At some point, they stopped making payments, but remained living in the home."

To differentiate the three overall ending financial position variants (loss, break-even, and gain positions), we describe the couple as making one of three different offers. We are careful to ensure the amounts are uniformly distributed about the break-even point. As previously reported, the loss position reads:

\footnotetext{
8 Again note that we are careful not to allow participants to go down the confusing path of nominal versus real returns.

${ }^{9}$ As evidenced by the consistency of our results, we are successful on this front.

10 There are many reasons why a person would not be able to make his mortgage payment. Freddie Mac's list of common reasons include a death in the family, divorce, unexpected major illness, curtailment of work hours, and unemployment. We acknowledge that this wide array of reasons will have a potentially differential impact on how forgiving a person is when viewing the morality of mortgage payment cessation by another. Still, one of the reasons had to be selected. As such, we acknowledge that to the extent different Non-Strategic Default reasons alter moral judgments, so too would our results vary.
} 
"The couple made a counter-offer to give back the house BUT pay the lender only $\$ 60,000$ to settle the loan.

Please rate the morality of the couple's counter-offer to give back the house AND pay the lender $\$ 60,000$, resulting in an overall loss of $-\$ 20,000(\$ 40,000-60,000)$ on the investment"

The break-even treatment reads:

"The couple made a counter-offer to give back the house BUT pay the lender only $\$ 40,000$ to settle the loan.

Please rate the morality of the couple's counter-offer to give back the house AND pay the lender $\$ 40,000$, resulting in an overall Break-Even $(\$ 40,000-40,000)$ on the investment."

\section{The gain position treatment reads:}

"The couple made a counter-offer to give back the house BUT pay the lender only $\$ 20,000$ to settle the loan.

Please rate the morality of the couple's counter-offer to give back the house AND pay the lender $\$ 20,000$, resulting in an overall Gain of $+\$ 20,000(\$ 40,000-60,000)$ on the investment."

In the first part of the experiment, we ask participants to report their level of perceived morality associated with just one of the nine offers. That is, we use what is called a "between subjects" design where no single participant sees, or is even aware of, the other eight treatments. This allows us to cloak the central hypothesis we seek to investigate. Alternatively stated, our results reflect an experimentally "revealed preference" of people's view of morality, not a traditional "stated preference" view, which can differ substantially, particularly on important, emotional issues such as morality.

We now turn our focus to asking participants what they believe to be a "morally appropriate" offer by the couple to settle the loan. Specifically, we write:

“The lender believes $\$ 80,000$ is a "fair and equity" settlement offer for both parties. Alternatively, for the couple to "break-even" on their overall investment in the home, they would need to pay the lender only $\$ 40,000$.

What do you believe would be a "morally appropriate" offer for the couple to make? \$

Whereas participants were previously asked to respond to a fixed scenario (a necessary structure to properly test our hypotheses), we now offer the participant a chance to answer a flexible, open-ended question. Our hypotheses remain the same in that we posit default intent and financial outcome matter a great deal when people suggest "morally appropriate" counter-offer amounts.

\section{Sample}

To understand the intervening roles of financial outcome and default intent on morality, we sought input from
2000 homeowners from across the United States. ${ }^{11}$ We used an existing network of homeowners who stand ready to participate in such tasks in exchange for a fee. ${ }^{12}$ We use a between-subjects design meaning that participants have no idea of our central research questions. Instead, they follow only one of the nine paths in our experiment. To ensure quality data, our collection efforts follow the protocols described in Seiler (2014b, 2015b, 2016b). After screening our 2000 participants, we are left with 1938 valid and complete responses to our experiment.

\section{Results}

Panel A of Table 1 reports the frequency of morality scores as well as several measures of central tendency (mean, median, mode, and standard deviation) under the nine different treatments ( $3 \times 3$ experimental design) where lower morality scores correspond to less moral actions. Under the No reason given (for default) columns 1-3, mean morality scores for the loss, break-even, and gain positions are 5.81, 5.87, and 4.61, respectively. Panel $\mathrm{B}$, which compares all relevant groupings of columns reveals that the loss and break-even positions are statistically non-distinguishable. However, ending in the gain position is perceived to be significantly less moral than ending in either of the other two. This test supports our first supposition that people do not like to see defaulters earn a positive return on their investment. Interestingly, they are just as accepting of the borrower breaking even overall as experiencing an overall loss. When comparing columns 4-6 and then separately comparing columns 7-9, we observe the exact same pattern. Controlling for default intent within each grouping, we consistently observe that people are more accepting of defaulters breaking-even at best, but are significantly morally opposed to them earning a profit from their actions. This result puts a very fine point on exactly what the public views as morally acceptable vs. not.

Shifting the focus onto default intent, we see another clear emergent pattern. Controlling for financial outcome, compare columns 7,1 , and 4 . In these loss position treatments, mean morality scores are 6.16, 5.81, and 5.14 for Non-Strategic Default, No reason given, and Strategic Default, respectively. At the break-even position, columns 8,2 , and 5 , the mean scores are $6.09,5.87$, and 4.61 , respectively. Finally, in the gain position, mean morality scores are 5.21, 4.61, and 4.09. In all three groupings, we clearly see a

\footnotetext{
11 While achieving our sample size goal would be easier if we additionally allowed renters into the pool, we restrict our sample to homeowners because many of the immorality viewpoints stem from such concepts as the foreclosure contagion effect, which is better understood/experienced by homeowners. Moreover, homeowners are typically more permanent in a neighborhood, are more financially impacted by surrounding defaults, and can reasonably be assumed to have a better understanding of what it means to hold a mortgage and be required to make mortgage payments. While these participant requests may seem overly demanding, past reviewers/editors have suggested we use homeowners instead of renters for the above stated reasons.

12 Since the questions we ask do not have "right" or "wrong" answers, we pay a fixed fee as opposed to other economic experiments where participants are incentivized to answer "correctly" by being awarded greater amounts with every "right" decision. This flat fee system is standard operating procedure in experimental frameworks.
} 
Table 1

Morality of mortgage default by default intent and financial outcome.

\begin{tabular}{|c|c|c|c|c|c|c|c|c|c|}
\hline \multicolumn{10}{|c|}{ Panel A: frequency distributions } \\
\hline \multirow[b]{2}{*}{$\begin{array}{l}\text { Morality } \\
\text { score }\end{array}$} & \multicolumn{3}{|c|}{ No reason given } & \multicolumn{3}{|c|}{ Strategic Default } & \multicolumn{3}{|c|}{ Non-Strategic Default } \\
\hline & $\begin{array}{l}(1) \\
\text { Loss } \\
\text { position }\end{array}$ & $\begin{array}{l}(2) \\
\text { Break } \\
\text { even }\end{array}$ & $\begin{array}{l}(3) \\
\text { Gain } \\
\text { position }\end{array}$ & $\begin{array}{l}(4) \\
\text { Loss } \\
\text { position }\end{array}$ & $\begin{array}{l}(5) \\
\text { Break } \\
\text { even }\end{array}$ & $\begin{array}{l}(6) \\
\text { Gain } \\
\text { position }\end{array}$ & $\begin{array}{l}(7) \\
\text { Loss } \\
\text { position }\end{array}$ & $\begin{array}{l}(8) \\
\text { Break } \\
\text { even }\end{array}$ & $\begin{array}{l}\text { (9) } \\
\text { Gain } \\
\text { position }\end{array}$ \\
\hline 1 & $3.9 \%$ & $2.3 \%$ & $12.0 \%$ & $9.1 \%$ & $8.7 \%$ & $17.4 \%$ & $1.3 \%$ & $1.4 \%$ & $5.3 \%$ \\
\hline 2 & $2.5 \%$ & $2.3 \%$ & $11.0 \%$ & $7.7 \%$ & $4.1 \%$ & $11.3 \%$ & $2.5 \%$ & $1.4 \%$ & $6.2 \%$ \\
\hline 3 & $6.9 \%$ & $9.1 \%$ & $14.1 \%$ & $7.7 \%$ & $14.2 \%$ & $12.2 \%$ & $7.2 \%$ & $5.4 \%$ & $12.8 \%$ \\
\hline 4 & $7.9 \%$ & $7.8 \%$ & $12.0 \%$ & $12.4 \%$ & $7.8 \%$ & $16.9 \%$ & $5.9 \%$ & $6.8 \%$ & $11.5 \%$ \\
\hline 5 & $18.2 \%$ & $19.2 \%$ & $9.4 \%$ & $13.4 \%$ & $16.0 \%$ & $15.0 \%$ & $13.1 \%$ & $14.9 \%$ & $15.0 \%$ \\
\hline 6 & $21.2 \%$ & $16.9 \%$ & $17.8 \%$ & $19.1 \%$ & $16.9 \%$ & $10.8 \%$ & $22.0 \%$ & $27.9 \%$ & $19.5 \%$ \\
\hline 7 & $13.8 \%$ & $15.1 \%$ & $6.3 \%$ & $9.6 \%$ & $11.9 \%$ & $6.1 \%$ & $16.9 \%$ & $18.9 \%$ & $10.2 \%$ \\
\hline 8 & $25.6 \%$ & $27.4 \%$ & $17.3 \%$ & $21.1 \%$ & $20.5 \%$ & $10.3 \%$ & $30.9 \%$ & $23.4 \%$ & $19.5 \%$ \\
\hline Sum & $100.0 \%$ & $100.0 \%$ & $100.0 \%$ & $100.0 \%$ & $100.0 \%$ & $100.0 \%$ & $100.0 \%$ & $100.0 \%$ & $100.0 \%$ \\
\hline Mean & 5.81 & 5.87 & 4.61 & 5.14 & 5.19 & 4.09 & 6.16 & 6.09 & 5.21 \\
\hline Median & 6 & 6 & 5 & 5 & 5 & 4 & 6 & 6 & 5 \\
\hline Mode & 8 & 8 & 6 & 8 & 8 & 1 & 8 & 6 & 6 and 8 \\
\hline$\sigma^{2}$ & 1.91 & 1.87 & 2.34 & 2.25 & 2.21 & 2.22 & 1.77 & 1.61 & 2.09 \\
\hline$N$ & 203 & 219 & 191 & 209 & 219 & 213 & 236 & 222 & 226 \\
\hline \multicolumn{8}{|c|}{ Panel B: Least Significant Difference post-hoc tests } & $\Delta$ & $p$-Value \\
\hline \multicolumn{8}{|c|}{ Column ( 1 vs. 4$)$ : loss position: no reason given vs. Strategic Default } & 0.664 & $0.001^{* * *}$ \\
\hline \multicolumn{8}{|c|}{ Column ( 1 vs. 7$)$ : loss position: no reason given vs. Non-Strategic Default } & -0.0349 & $0.073^{*}$ \\
\hline \multicolumn{8}{|c|}{ Column (4 vs. 7): loss position: Strategic Default vs. Non-Strategic Default } & -1.013 & $0.000^{* * *}$ \\
\hline \multicolumn{8}{|c|}{ Column (2 vs. 5): break even: no reason given vs. Strategic Default } & 0.680 & 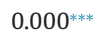 \\
\hline \multicolumn{8}{|c|}{ Column (2 vs. 8): break even: no reason given vs. Non-Strategic Default } & -0.218 & 0.261 \\
\hline \multicolumn{8}{|c|}{ Column (5 vs. 8): break even: Strategic Default vs. Non-Strategic Default } & -0.898 & $0.000^{* * *}$ \\
\hline \multicolumn{8}{|c|}{ Column (3 vs. 6): gain position: no reason given vs. Strategic Default } & 0.513 & $0.011^{* *}$ \\
\hline \multicolumn{8}{|c|}{ Column ( 3 vs. 9): gain position: no reason given vs. Non-Strategic Default } & -0.605 & $0.003^{* * * *}$ \\
\hline \multicolumn{8}{|c|}{ Column (6 vs. 9): gain position: Strategic Default vs. Non-Strategic Default } & -1.118 & $0.000^{* * *}$ \\
\hline \multicolumn{10}{|c|}{ Does financial outcome matter? } \\
\hline \multicolumn{8}{|c|}{ Column ( 1 vs. 2$)$ : no reason given: loss position vs. break even } & -0.064 & 0.746 \\
\hline \multicolumn{8}{|c|}{ Column ( 1 vs. 3$)$ : no reason given: loss position vs. gain position } & 1.201 & $0.000^{* * *}$ \\
\hline \multicolumn{8}{|c|}{ Column ( 2 vs. 3): no reason given: break even vs. gain position } & 1.265 & $0.000^{* * * *}$ \\
\hline \multicolumn{8}{|c|}{ Column (4 vs. 5): Strategic Default: loss position vs. break even } & -0.048 & 0.806 \\
\hline \multicolumn{8}{|c|}{ Column (4 vs. 6): Strategic Default: loss position vs. gain position } & 1.050 & $0.000^{* * * *}$ \\
\hline \multicolumn{8}{|c|}{ Column (5 vs. 6): Strategic Default: break even vs. gain position } & 1.098 & $0.000^{* * *}$ \\
\hline \multicolumn{8}{|c|}{ Column (7 vs. 8): Non-Strategic Default: loss position vs. break even } & 0.067 & 0.726 \\
\hline \multicolumn{8}{|c|}{ Column (7 vs. 9): Non-Strategic Default: loss position vs. gain position } & 0.944 & $0.000^{* * * *}$ \\
\hline \multicolumn{8}{|c|}{ Column (8 vs. 9): Non-Strategic Default: break even vs. gain position } & 0.878 & $0.000^{* * *}$ \\
\hline
\end{tabular}

This table reports the frequency of morality scores as well as several measures of central tendency (mean, median, mode, and standard deviation) under nine different treatments (a $3 \times 3$ experimental design). No reason given does not share the reason the couple defaulted on the mortgage. Strategic Default shares that the couple can afford to make their payments, but has stopped making monthly mortgage payments because they believe it is no longer in their best financial interests. Non-Strategic Default shares that after a series of financial setbacks brought on by an unexpected major illness, this couple is no longer able, and has thus stopped making their monthly mortgage payments. Loss position refers to the couple making a settlement counter-offer of $\$ 60,000$ which leaves them with an overall loss on their investment. Break even refers to the couple making a settlement counter-offer of $\$ 40,000$ which leaves them with an overall break-even position on their investment. Gain position refers to the couple making a settlement counter-offer of $\$ 20,000$ which leaves them with an overall gain on their investment. Panel A reports the frequency distribution as well as the measures of central tendency. Panel B reports Least Significant Difference (LSD) post-hoc tests of statistical significance. $\Delta$ refers to the difference in the mean morality scores between paired treatments.

* Statistical significance at the $90 \%$ level.

** Statistical significance at the $95 \%$ level.

*** Statistical significance at the $99 \%$ level.

consistent result that people are more morally forgiving of non-strategic defaulters and significantly less morally forgiving of strategic defaulters.

Combining the two treatment effects yields a powerful result. Specifically, the lowest mean score across the nine treatments is associated with strategic defaulters who end in the gains position. This is consistent with our discussion to this point that people strongly oppose defaulters ending in the gain position, and that people view strategic mortgage default as less moral than in other treatments.
All results in Table 1 are perfectly consistent with our two central hypotheses and are statistically robust.

Panel A of Table 2 reports the cumulative distributions of what the respondent believes would be a "morally appropriate" amount for the couple to pay to settle their debt with the lender under each of the nine treatments. Again focusing first on financial outcome, under the No reason given columns (1-3), we see that mean offer scores smoothly transition from $\$ 49,318,47,023$, to $\$ 43,764$ under the loss, break-even, and gain positions, respectively. 
Table 2

Settlement counter-offers by default intent and financial outcome.

\begin{tabular}{|c|c|c|c|c|c|c|c|c|c|c|}
\hline \multirow[t]{3}{*}{ CDF of offers } & \multicolumn{3}{|c|}{ No reason given } & \multicolumn{3}{|c|}{ Strategic Default } & \multicolumn{3}{|c|}{ Non-Strategic Default } & \multirow[t]{3}{*}{ Overall } \\
\hline & $(1)$ & $(2)$ & (3) & $(4)$ & $(5)$ & $(6)$ & $(7)$ & $(8)$ & (9) & \\
\hline & $\begin{array}{l}\text { Loss } \\
\text { position }\end{array}$ & $\begin{array}{l}\text { Break } \\
\text { even }\end{array}$ & $\begin{array}{l}\text { Gain } \\
\text { position }\end{array}$ & $\begin{array}{l}\text { Loss } \\
\text { position }\end{array}$ & $\begin{array}{l}\text { Break } \\
\text { even }\end{array}$ & $\begin{array}{l}\text { Gain } \\
\text { position }\end{array}$ & $\begin{array}{l}\text { Loss } \\
\text { position }\end{array}$ & $\begin{array}{l}\text { Break } \\
\text { even }\end{array}$ & $\begin{array}{l}\text { Gain } \\
\text { position }\end{array}$ & \\
\hline \$0k & $4.9 \%$ & $6.4 \%$ & $2.1 \%$ & $3.3 \%$ & $5.9 \%$ & $1.4 \%$ & $5.9 \%$ & $5.0 \%$ & $5.8 \%$ & $4.6 \%$ \\
\hline \$10k & $11.3 \%$ & $8.7 \%$ & $5.2 \%$ & $7.7 \%$ & $10.0 \%$ & $2.8 \%$ & $8.1 \%$ & $7.7 \%$ & $9.3 \%$ & $7.9 \%$ \\
\hline \$20k & $15.3 \%$ & $11.4 \%$ & $16.2 \%$ & $9.6 \%$ & $12.3 \%$ & $11.7 \%$ & $14.0 \%$ & $9.5 \%$ & $22.1 \%$ & $13.6 \%$ \\
\hline \$30k & $15.3 \%^{\mathrm{a}}$ & $12.8 \%$ & $22.0 \%$ & $10.0 \%$ & $13.7 \%$ & $17.4 \%$ & $16.5 \%$ & $12.2 \%$ & $32.7 \%$ & $17.0 \%$ \\
\hline$\$ 40 k$ & $36.5 \%$ & $51.1 \%$ & $64.9 \%$ & $34.4 \%$ & $44.3 \%$ & $61.5 \%$ & $41.9 \%$ & $51.4 \%$ & $75.2 \%$ & $51.2 \%$ \\
\hline \$50k & $51.2 \%$ & $62.6 \%$ & $72.3 \%$ & $42.6 \%$ & $54.3 \%$ & $68.1 \%$ & $57.6 \%$ & $65.3 \%$ & $81.9 \%$ & $61.8 \%$ \\
\hline \$60k & $80.8 \%$ & $84.5 \%$ & $86.4 \%$ & $67.0 \%$ & $75.8 \%$ & $81.2 \%$ & $83.1 \%$ & $87.4 \%$ & $92.0 \%$ & $82.1 \%$ \\
\hline \$70k & $84.7 \%$ & $88.1 \%$ & $88.0 \%$ & $73.7 \%$ & $78.5 \%$ & $82.2 \%$ & $87.7 \%$ & $88.7 \%$ & $92.5 \%$ & $85.0 \%$ \\
\hline \$80k & $100.0 \%$ & $100.0 \%$ & $100.0 \%$ & $100.0 \%$ & $100.0 \%$ & $100.0 \%$ & $100.0 \%$ & $100.0 \%$ & $100.0 \%$ & $100.0 \%$ \\
\hline Mean & $\$ 49,318$ & $\$ 47,023$ & $\$ 43,764$ & $\$ 54,873$ & $\$ 49,966$ & $\$ 47,031$ & $\$ 48,102$ & $\$ 46,888$ & $\$ 38,491$ & $\$ 47,243$ \\
\hline Median & $\$ 50,000$ & $\$ 40,000$ & $\$ 40,000$ & $\$ 60,000$ & $\$ 50,000$ & $\$ 40,000$ & $\$ 50,000$ & $\$ 40,000$ & $\$ 40,000$ & $\$ 40,000$ \\
\hline Mode & $\$ 60,000$ & $\$ 40,000$ & $\$ 40,000$ & $\$ 80,000$ & $\$ 40,000$ & $\$ 40,000$ & $\$ 40,000$ & $\$ 40,000$ & $\$ 40,000$ & $\$ 40,000$ \\
\hline$\sigma^{2}$ & $\$ 21,896$ & $\$ 20,216$ & $\$ 19,354$ & $\$ 21,513$ & $\$ 22,631$ & $\$ 19,659$ & $\$ 20,670$ & $\$ 19,154$ & $\$ 19,052$ & $\$ 20,884$ \\
\hline$N$ & 203 & 219 & 191 & 209 & 219 & 213 & 236 & 222 & 226 & 1938 \\
\hline \multicolumn{8}{|c|}{ Panel B: Least Significant Difference post-hoc tests } & \multicolumn{3}{|c|}{ Does default intent matter? } \\
\hline \multicolumn{8}{|c|}{ Column ( 1 vs. 4 ): loss position: no reason given vs. Strategic Default } & $-\$ 5556$ & $0.006^{* * *}$ & \\
\hline \multicolumn{8}{|c|}{ Column ( 1 vs. 7 ): loss position: no reason given vs. Non-Strategic Default } & $\$ 1216$ & 0.535 & \\
\hline \multicolumn{8}{|c|}{ Column (4 vs. 7): loss position: Strategic Default vs. Non-Strategic Default } & $\$ 6772$ & $0.001^{* * *}$ & \\
\hline \multicolumn{8}{|c|}{ Column ( 2 vs. 5 ): break even: no reason given vs. Strategic Default } & $-\$ 2943$ & 0.133 & \\
\hline \multicolumn{8}{|c|}{ Column (2 vs. 8 ): break even: no reason given vs. Non-Strategic Default } & $\$ 135.26$ & 0.945 & \\
\hline \multicolumn{8}{|c|}{ Column (5 vs. 8): break even: Strategic Default vs. Non-Strategic Default } & $\$ 3078$ & 0.115 & \\
\hline \multicolumn{8}{|c|}{ Column (3 vs. 6): gain position: no reason given vs. Strategic Default } & $-\$ 3266$ & 0.110 & \\
\hline \multicolumn{8}{|c|}{ Column (3 vs. 9): gain position: no reason given vs. Non-Strategic Default } & $\$ 5273$ & $0.009^{* * * *}$ & \\
\hline \multicolumn{8}{|c|}{ Column (6 vs. 9): gain position: Strategic Default vs. Non-Strategic Default } & $\$ 8540$ & $0.000^{* * *}$ & \\
\hline \multicolumn{11}{|c|}{ Does financial outcome matter? } \\
\hline \multicolumn{8}{|c|}{ Column ( 1 vs. 2 ): no reason given: loss position vs. break even } & $\$ 2295$ & 0.251 & \\
\hline \multicolumn{8}{|c|}{ Column ( 1 vs. 3 ): no reason given: loss position vs. gain position } & $\$ 5553$ & $0.007^{* * *}$ & \\
\hline \multicolumn{8}{|c|}{ Column ( 2 vs. 3 ): no reason given: break even vs. gain position } & $\$ 3258$ & 0.108 & \\
\hline \multicolumn{8}{|c|}{ Column (4 vs. 5): Strategic Default: loss position vs. break even } & $\$ 4907$ & $0.013^{* *}$ & \\
\hline \multicolumn{8}{|c|}{ Column (4 vs. 6): Strategic Default: loss position vs. gain position } & $\$ 7842$ & $0.000^{* * * *}$ & \\
\hline \multicolumn{8}{|c|}{ Column (5 vs. 6): Strategic Default: break even vs. gain position } & $\$ 2935$ & 0.137 & \\
\hline \multicolumn{8}{|c|}{ Column (7 vs. 8): Non-Strategic Default: loss position vs. break even } & $\$ 1214$ & 0.526 & \\
\hline \multicolumn{8}{|c|}{ Column (7 vs. 9): Non-Strategic Default: loss position vs. gain position } & $\$ 9610$ & $0.000^{* * * *}$ & \\
\hline Column ( 8 vs. & ): Non-Strc & gic Defaul & break ever & vs. gain p & sition & & & $\$ 8396$ & $0.000^{\text {**** }}$ & \\
\hline
\end{tabular}

This table reports the cumulative distributions of what the respondent believes would be a "morally appropriate amount for the couple to pay to settle their debt with the lender" under each of the nine treatments. No reason given does not share the reason the couple defaulted on the mortgage. Strategic Default shares that the couple can afford to make their payments, but has stopped making monthly mortgage payments because they believe it is no longer in their best financial interests. Non-Strategic Default shares that after a series of financial setbacks brought on by an unexpected major illness, this couple is no longer able, and has thus stopped making their monthly mortgage payments. Loss position refers to the couple making a settlement counter-offer of $\$ 60,000$ which leaves them with an overall loss on their investment. Break even refers to the couple making a settlement counter-offer of $\$ 40,000$ which leaves them with an overall break-even position on their investment. Gain position refers to the couple making a settlement counter-offer of $\$ 20,000$ which leaves them with an overall gain on their investment. Panel A reports the Cumulative distribution of offers as well as the measures of central tendency (mean, median, mode, and standard deviation). Panel B reports Least Significant Difference (LSD) post-hoc tests of statistical significance. $\Delta$ refers to the difference in the mean counter-offers between paired treatments.

* Statistical significance at the $90 \%$ level.

** There were no offers made in this cell (i.e., at $\$ 30,000$ ).

*** There were no offers made in this cell (i.e., at $\$ 30,000$ ).

a There were no offers made in this cell (i.e., at $\$ 30,000$ ).

The same general pattern emerges in columns 4-6 and in columns 7-9. Based on the levels of statistical significance in Panel B, we conclude there is once again evidentiary support for the relevance of the couple's ultimate financial outcome.

When examining the impact of default intent, we compare column groupings: "7, 1, and 4," "8, 2, and 5," and " 9,3 , and 6 " just as we did in the prior table.
Again we observe a numerical consistency supporting the idea that default intent matters. Also consistent with our prior results is that the Strategic Default treatments reported in columns 4-6 are associated with the highest "morally appropriate" suggested settlement amounts. This implies that people once again do not find it as acceptable to profit from a default when it is strategic in nature. 
Table 3

Univariate summary statistics.

\begin{tabular}{lrcccc}
\hline Variable & Obs. & Mean/median & Std. dev. & Minimum & Maximum \\
\hline $\begin{array}{l}\text { Behavioral characteristics } \\
\text { Blames the lender }\end{array}$ & & & & & \\
9-point scale & 1938 & 3.79 & 2.04 & 1 & 9 \\
Dichotomous scale & 1938 & $55.66 \%$ & 0.48 & 0 & 1 \\
Home as an investment & & & & & \\
9-point scale & 1938 & 6.99 & 2.05 & 1 & 9 \\
Dichotomous scale & 1938 & $7.89 \%$ & 0.27 & 0 & 1 \\
Previous default & 1938 & $6.19 \%$ & 0.24 & 0 & 1 \\
Non-Strategic Default & 1938 & $89.17 \%$ & 0.23 & 0 & 1 \\
Strategic Default & 1938 & $10.83 \%$ & 0.08 & 0 & 1 \\
Demographics & & & & & \\
Child dummy & 1938 & $51.08 \%$ & 0.50 & 0 & 1 \\
Male dummy & 1938 & $49.12 \%$ & 0.50 & 0 & 1 \\
Married dummy & 1938 & $61.00 \%$ & 0.49 & 0 & 1 \\
Age & 1938 & 36.84 & 11.34 & 18 & 79 \\
Income & 1938 & 3.34 & 1.52 & 1 & 7 \\
Ethnicity & 1938 & & & & \\
Caucasian & 1630 & $83.08 \%$ & & & \\
African American & 101 & $5.21 \%$ & & & \\
Hispanic & 92 & $4.75 \%$ & & & \\
Asian & 98 & $5.06 \%$ & & & \\
Other & 37 & $1.91 \%$ & & & \\
Region & 1938 & & & & \\
Midwest & 431 & $22.24 \%$ & & & \\
Northeast & 386 & $19.92 \%$ & & & \\
Southwest & 694 & $35.81 \%$ & & & \\
West & 427 & $22.03 \%$ & & & \\
\hline
\end{tabular}

This table reports univariate summary statistics for variables considered in the regression analysis. Behavioral characteristics include the following. Blames the Lender is measured on both a 9-point scale (where $1=$ the lender is more to blame for the current housing crisis, and $9=$ the borrower is more to blame); This variable is also converted into a dummy variable for whether the respondent more so blames the lender $(=1)$ as opposed to the borrower $(=0)$ for the current housing crisis; A similar pair of variables is collected relating to whether the homeowner views his home as an investment (1 on a scale from 1 to 9 ) as opposed to a consumption good (9 on a scale from 1 to 9); Home as an investment dummy $=1$ for more of an investment, and $=0$ for more of a consumption good. Previous default $=1$ if the respondent previously defaulted on a mortgage, 0 otherwise. Of those who have defaulted, respondents self-select into either Non-Strategic Default or a Strategic Default. Demographic variables include Child dummy $=1$ for children, 0 otherwise; Male dummy $=1$ for males, 0 otherwise; Married dummy $=1$ if married, 0 otherwise; Age; and Income on a scale from $1=$ under $\$ 20,000$, to $7=$ over $\$ 120,000$. Finally, Ethnicity and Region of the country where the respondent is domiciled are reported by category.

\subsection{A multivariate analysis}

When transactions data are used to answer research questions, it is understood that there are numerous explanatory variables changing simultaneously. For this reason, a multivariate technique, such as regression analysis, is used in an attempt to hold all else constant. In an experimental design, ceteris paribus is achieved on the front end of the study by isolating the variables of interest through a carefully crafted experiment.

This methodological difference notwithstanding, we recognize that there may be respondent characteristics that might skew personal views of default morality in one direction or another. To this end, we model people's moral views on default by considering not only our two main hypotheses, but also including a number of other independent variables. Table 3 reports summary statistics for variables we consider in our multivariate regression analysis to follow.

The variable Blames the lender is collected on a 9-point scale where $1=$ the lender is more to blame for the cur- rent housing crisis, and $9=$ the borrower is more to blame. This variable is also converted into a dummy variable for whether the respondent more so blames the lender $(=1)$ as opposed to the borrower $(=0)$ for the current housing crisis. We hypothesize participants who more so blame the lender will be more sympathetic towards a defaulting borrower since it is the lender who got them into the situation in the first place. Alternatively, those who view the borrower as being more to blame should be less forgiving of a default since it is perceived to be their fault for getting themselves into this situation.

A similar pair of variables is collected relating to whether the homeowner views his home as an investment ( 1 on a scale from 1 to 9 ) as opposed to a consumption good (9 on a scale from 1 to 9); Home as an investment dummy $=1$ for more of an investment, and $=0$ for more of a consumption good. While not as important in the first regression where the dependent variable is the morality of default, we hypothesize that in our second regression where the dependent variable is the proposed "morally appropriate" settlement amount, people who view their 
Table 4

Regression results explaining morality of default.

\begin{tabular}{|c|c|c|c|}
\hline Independent variables & $\begin{array}{l}\text { Model I- } \\
\text { treatments only }\end{array}$ & $\begin{array}{l}\text { Model II - treatments and } \\
\text { behavioral characteristics }\end{array}$ & $\begin{array}{l}\text { Model III- } \\
\text { all variables }\end{array}$ \\
\hline Intercept & $\begin{array}{l}5.212^{* * *} \\
(0.135)\end{array}$ & $\begin{array}{l}4.672^{* * *} \\
(0.143)\end{array}$ & $\begin{array}{l}4.790^{\text {**** }} \\
(0.276)\end{array}$ \\
\hline \multicolumn{4}{|l|}{ Treatment dummy variables } \\
\hline No reason given/loss position & $\begin{array}{l}0.595^{* * *} \\
(0.197)\end{array}$ & $\begin{array}{l}0.596^{* * * *} \\
(0.192)\end{array}$ & $\begin{array}{l}0.591^{\text {**** }} \\
(0.193)\end{array}$ \\
\hline No reason given/break even & $\begin{array}{l}0.660^{* * * *} \\
(0.193)\end{array}$ & $\begin{array}{l}0.684^{* * *} \\
(0.188)\end{array}$ & $\begin{array}{l}0.686^{* * *} \\
(0.189)\end{array}$ \\
\hline No reason given/gain position & $\begin{array}{l}-0.605 * * * \\
(0.200)\end{array}$ & $\begin{array}{l}-0.621^{* * *} \\
(0.195)\end{array}$ & $\begin{array}{l}-0.650^{* * *} \\
(0.196)\end{array}$ \\
\hline Strategic default/loss position & $\begin{array}{c}-0.069 \\
(0.195)\end{array}$ & $\begin{array}{c}-0.090 \\
(0.190)\end{array}$ & $\begin{array}{c}-0.081 \\
(0.191)\end{array}$ \\
\hline Strategic default//break even & $\begin{array}{c}-0.021 \\
(0.193)\end{array}$ & $\begin{array}{c}0.042 \\
(0.188)\end{array}$ & $\begin{array}{c}0.067 \\
(0.189)\end{array}$ \\
\hline Strategic default//gain position & $\begin{array}{c}-1.118^{* * * *} \\
(0.194)\end{array}$ & $\begin{array}{l}-1.087^{* * * *} \\
(0.189)\end{array}$ & $\begin{array}{l}-1.099 * * * \\
(0.190)\end{array}$ \\
\hline Non-Strategic Default/loss position & $\begin{array}{l}0.944^{* * * *} \\
(0.189)\end{array}$ & $\begin{array}{l}0.969^{* * *} \\
(0.185)\end{array}$ & $\begin{array}{l}0.976^{* * * *} \\
(0.185)\end{array}$ \\
\hline Non-Strategic Default//break even & $\begin{array}{l}0.878^{* * *} \\
(0.192)\end{array}$ & $\begin{array}{l}0.933^{* * * *} \\
(0.188)\end{array}$ & $\begin{array}{l}0.934^{* * *} \\
(0.188)\end{array}$ \\
\hline \multicolumn{4}{|l|}{ Behavioral characteristics } \\
\hline Blames the lender & & $\begin{array}{l}0.908^{* * *} \\
(0.091)\end{array}$ & $\begin{array}{l}0.864^{* * *} \\
(0.092)\end{array}$ \\
\hline Home as an investment & & $\begin{array}{c}0.096 \\
(0.167)\end{array}$ & $\begin{array}{c}0.093 \\
(0.169)\end{array}$ \\
\hline Past strategic default & & $\begin{array}{l}1.271^{* *} \\
(0.553)\end{array}$ & $\begin{array}{l}1.270^{* *} \\
(0.554)\end{array}$ \\
\hline \multicolumn{4}{|l|}{ Demographics } \\
\hline Male dummy & & & $\begin{array}{c}0.178^{*} \\
(0.093)\end{array}$ \\
\hline Child dummy & & & $\begin{array}{l}-0.120 \\
(0.100)\end{array}$ \\
\hline Minority dummy & & & $\begin{array}{c}0.143 \\
(0.122)\end{array}$ \\
\hline Married dummy & & & $\begin{array}{c}0.006 \\
(0.106)\end{array}$ \\
\hline Income & & & $\begin{array}{c}-0.046 \\
(0.031)\end{array}$ \\
\hline Age & & & $\begin{array}{c}0.006 \\
(0.004)\end{array}$ \\
\hline \multicolumn{4}{|l|}{ Region ( $N-1$ dummies) } \\
\hline Midwest dummy & & & $\begin{array}{l}-0.112 \\
(0.137)\end{array}$ \\
\hline Northeast dummy & & & $\begin{array}{c}-0.074 \\
(0.140)\end{array}$ \\
\hline Southeast dummy & & & $\begin{array}{l}-0.130 \\
(0.123)\end{array}$ \\
\hline Observations & 1938 & 1938 & 1938 \\
\hline F-statistic & 25.251 & 28.912 & 16.553 \\
\hline$p$-Value & $0.000^{* * * *}$ & $0.000^{* * *}$ & $0.000^{* * *}$ \\
\hline Adjusted $R^{2}$ & 0.091 & 0.137 & 0.138 \\
\hline
\end{tabular}

This table reports the results from three regressions where the dependent variable is the morality measure on an 8 -point scale where $1=$ not at all moral, to $8=$ completely moral. Treatment dummy variables represent the $8(N-1)$ treatment effects (consistent with prior tables) with the last treatment representing the holdout pool. Behavioral characteristics section includes three variables. Blames the Lender is measured as a dummy variable where $1=$ the respondent more so blames the lender, 0 otherwise; Home as an Investment $=1$ when the homeowner views his home as more of an investment, and $=0$ when it is viewed as more of a consumption good. Past strategic Default $=1$ if the respondent has defaulted on a mortgage in the past. Demographic includes seven variables. Male dummy $=1$ for men, 0 otherwise; Child dummy $=1$ if the respondent has at least one dependent child living at home, $0=$ otherwise. Minority dummy $=1$ if the respondent is not Caucasian, 0 otherwise; Married dummy $1=$ married, 0 otherwise; Income on a scale from $1=$ under $\$ 20,000$, to $7=$ over $\$ 120,000$; Age; and Region. Midwest $=1$ for Midwest, 0 otherwise; Northeast $=1$ for Northeast, 0 otherwise; and Southeast $=1$ for Southeast, 0 otherwise. West is the holdout region. Model I reports results from including only the 8 treatment effects. Model II reports results from including the treatment effects and behavioral characteristics, while Model III reports results when including all the explanatory variables. Standard errors are reported inside the parentheses.

* Statistical significance at the $90 \%$ level.

** Statistical significance at the $95 \%$ level

*** Statistical significance at the $99 \%$ level. 
Table 5

Regression results explaining "morally appropriate” counter-offers.

\begin{tabular}{|c|c|c|c|}
\hline Independent variables & $\begin{array}{l}\text { Model I- } \\
\text { treatments only }\end{array}$ & $\begin{array}{l}\text { Model II - treatments and } \\
\text { behavioral characteristics }\end{array}$ & $\begin{array}{l}\text { Model III- } \\
\text { all variables }\end{array}$ \\
\hline Intercept & $\begin{array}{l}38491.372 * * * \\
(1363.333)\end{array}$ & $\begin{array}{l}43638.229^{* * * *} \\
(1447.131)\end{array}$ & $\begin{array}{l}34115.839 * * * \\
(2767.012)\end{array}$ \\
\hline \multicolumn{4}{|l|}{ Treatment dummy variables } \\
\hline No reason given/loss position & $\begin{array}{l}10826.264^{* * * *} \\
(1981.903)\end{array}$ & $\begin{array}{l}10857.308^{* * *} \\
(1936.214)\end{array}$ & $\begin{array}{l}11257.260^{* * * *} \\
(1933.112)\end{array}$ \\
\hline No reason given/break even & $\begin{array}{l}8531.459^{* * * *} \\
(1,943.389)\end{array}$ & $\begin{array}{l}8289.446^{* * *} \\
(1,898.239)\end{array}$ & $\begin{array}{l}8141.467^{* * * *} \\
(1892.164)\end{array}$ \\
\hline No reason given/gain position & $\begin{array}{l}5273.026^{* * * * *} \\
(2014.435)\end{array}$ & $\begin{array}{l}5362.278^{* * * * *} \\
(1969.206)\end{array}$ & $\begin{array}{l}5866.902^{* * *} \\
(1964.665)\end{array}$ \\
\hline Strategic default/loss position & $\begin{array}{l}16381.834^{* * *} \\
(1966.859)\end{array}$ & $\begin{array}{l}16655.9933^{* * *} \\
(1922.333)\end{array}$ & $\begin{array}{l}16639.767^{* * *} \\
(1912.674)\end{array}$ \\
\hline Strategic default//break even & $\begin{array}{l}11474.473^{* * * * *} \\
(1943.389)\end{array}$ & $\begin{array}{l}10862.838^{* * * *} \\
(1899.540)\end{array}$ & $\begin{array}{l}11089.741^{* * * *} \\
(1893.788)\end{array}$ \\
\hline Strategic default//gain position & $\begin{array}{l}8539.516 * * * * \\
(1957.241)\end{array}$ & $\begin{array}{l}8248.045^{* * * *} \\
(1911.825)\end{array}$ & $\begin{array}{l}8196.938^{* * *} \\
(1908.522)\end{array}$ \\
\hline Non-Strategic Default/loss position & $\begin{array}{l}9610.327^{* * * * *} \\
(1907.510)\end{array}$ & $\begin{array}{l}9296.008^{* * * *} \\
(1865.436)\end{array}$ & $\begin{array}{l}9511.574^{\text {**** }} \\
(1855.903)\end{array}$ \\
\hline Non-Strategic Default//break even & $\begin{array}{l}8396.196 * * * \\
(1936.709)\end{array}$ & $\begin{array}{l}7765.788^{* * * *} \\
(1894.153)\end{array}$ & $\begin{array}{l}7969.885^{* * * *} \\
(1888.076)\end{array}$ \\
\hline \multicolumn{4}{|l|}{ Behavioral characteristics } \\
\hline Blames the lender & & $\begin{array}{c}-7992.677^{\text {***** }} \\
(916.578)\end{array}$ & $\begin{array}{c}-7930.624^{* * * *} \\
(923.177)\end{array}$ \\
\hline Home as an investment & & $\begin{array}{c}-4506.516 \\
(1689.959)\end{array}$ & $\begin{array}{c}-3768.182^{* *} \\
(1700.529)\end{array}$ \\
\hline Past strategic default & & $\begin{array}{c}-21423.115^{* * * *} \\
(5577.483)\end{array}$ & $\begin{array}{c}-21076.568^{\text {***** }} \\
(5555.928)\end{array}$ \\
\hline \multicolumn{4}{|l|}{ Demographics } \\
\hline Male dummy & & & $\begin{array}{c}-177.043 \\
(933.584)\end{array}$ \\
\hline Child dummy & & & $\begin{array}{l}-497.715 \\
(1003.509)\end{array}$ \\
\hline Minority dummy & & & $\begin{array}{c}-5580.360 * * * \\
(1224.684)\end{array}$ \\
\hline Married dummy & & & $\begin{array}{c}210.548 \\
(1062.351)\end{array}$ \\
\hline Income & & & $\begin{array}{c}929.947^{\text {***** }} \\
(311.659)\end{array}$ \\
\hline Age & & & $\begin{array}{c}53.922 \\
(41.776)\end{array}$ \\
\hline \multicolumn{4}{|l|}{ Region ( $N-1$ dummies) } \\
\hline Midwest dummy & & & $\begin{array}{l}-995.214 \\
(1373.818)\end{array}$ \\
\hline Northeast dummy & & & $\begin{array}{c}-885.982 \\
(1408.216)\end{array}$ \\
\hline Southeast dummy & & & $\begin{array}{c}452.979 \\
(1230.734)\end{array}$ \\
\hline Observations & 1938 & 1938 & 1938 \\
\hline F-statistic & 11.011 & 16.682 & 10.269 \\
\hline$p$-Value & $0.000^{* * * *}$ & $0.000^{* * * *}$ & $0.000^{* * * *}$ \\
\hline Adjusted $R^{2}$ & .094 & 0.082 & 0.037 \\
\hline
\end{tabular}

This table reports the results from three regressions where the dependent variable is the deemed "morally appropriate" counter-offer (which ranges from $\$ 0$ to $\$ 80,000$ ). Treatment dummy variables represent the 8 $(N-1)$ treatment effects (consistent with the prior tables) with the last treatment representing the holdout pool. Behavioral characteristics section includes three variables. Blames the lender is measured as a dummy variable where $1=$ the respondent more so blames the lender, 0 otherwise; Home as an investment $=1$ when the homeowner views his home as more of an investment, and $=0$ when it is viewed as more of a consumption good. Past strategic Default $=1$ if the respondent has defaulted on a mortgage in the past. Demographic includes seven variables. Male dummy $=1$ for men, 0 otherwise; Child dummy=1 if the respondent has at least one dependent child living at home, $0=$ otherwise. Minority dummy $=1$ if the respondent is not Caucasian, 0 otherwise; Married dummy $1=$ married, 0 otherwise; Income on a scale from $1=$ under $\$ 20,000$, to $7=$ over $\$ 120,000$; Age; and Region. Midwest $=1$ for Midwest, 0 otherwise; Northeast $=1$ for Northeast, 0 otherwise; and Southeast $=1$ for Southeast, 0 otherwise. West is the holdout region. Model I reports results from including only the 8 treatment effects. Model II reports results from including the treatment effects and behavioral characteristics, while Model III reports results when including all the explanatory variables. Standard errors are reported inside the parentheses.

* Statistical significance at the $90 \%$ level.

** Statistical significance at the $95 \%$ level.

*** Statistical significance at the $99 \%$ level. 
home as more of an investment will suggest a lower settlement payoff in an attempt to preserve the return on the investment.

Previous default $=1$ if the respondent previously defaulted on a mortgage, and 0 otherwise. Of those who have defaulted, respondents self-select into either a NonStrategic Default or a Strategic default. We hypothesize that those who have previously defaulted, particularly if that default was strategic in nature, will be far more understanding of defaulters in general and will therefore suggest a lower settlement payoff amount.

In the first regression where we model the morality of default, we include a series of respondent demographic data as more of an exploratory exercise rather than based on a series of hypotheses. Child dummy $=1$ for children, 0 otherwise. Male dummy=1 for males, 0 otherwise. Married dummy $=1$ if married, 0 otherwise. Age is simply the age of the respondent. Income is measured on a scale from $1=$ under $\$ 20,000$, to $7=$ over $\$ 120,000$. Respondents with greater income are hypothesized to be willing and able to offer a higher settlement amount. As such, in the second regression, we anticipate a positive sign. Finally, Ethnicity and Region of the country where the respondent is domiciled are reported by category.

Table 4 reports the results from three regressions where the dependent variable is the morality of mortgage default. ${ }^{13}$ In the first model, we only include eight $(N-1)$ of the treatment pools as independent variables. Consistent with our hypotheses (and Table 1), strategic defaulters are met with the greatest moral opposition from the public. Moreover, those who end in a gain position are viewed as behaving significantly less morally than those who do not. Model II adds the three Behavioral characteristics to the list of explanatory variables, while Model III further includes demographic data. Consistent with our hypothesis, those who blame the lender for the current financial crisis more so than the borrower are significantly less judgmental of mortgage defaulters. Also consistent with expectations is the finding that those who have strategically defaulted in the past are more forgiving of defaulters. Concerning demographic characteristics, males are found to be significantly less morally opposed to default than females. No other demographic variables are found to be significant. Note the stability in coefficient estimates across all three columns suggesting a level of stability in the reported relations.

Table 5 reports the results from three regressions where the dependent variable is the deemed "morally appropriate" counter-offer (which ranges from $\$ 0$ to $\$ 80,000$ ). Model I again reports the results from eight $(N-1)$ treatment pools. The coefficients are all statistically significant and consistent with the univariate conclusions reported in Table 2. Model II reports the inclusion of the Behavioral characteristics as independent variables. As hypothesized, those who more so blame the lender for the financial cri-

\footnotetext{
13 We report the results from an OLS regression, but as a robustness check, we also split the dependent variable into a dummy variable where 1-4 is categorized an "immoral," while scores of 5-8 are rescaled as "moral." The results from this Logistic regression are extremely similar and suggest an overall robustness in terms of model specification.
}

sis make significantly lower settlement offers. Moreover, those who view their home as more of an investment (as opposed to a consumption good) also make significantly lower settlement offers supporting the notion that by doing so they hope to preserve as great a portion of their return on investment as possible. Finally, those who have strategically defaulted on a mortgage in the past offer significantly lower settlements than those who have not. ${ }^{14}$ Model III includes demographic independent variables and shows that minorities make significantly lower settlement offers, while those with greater incomes make significantly higher settlement offers.

\section{Conclusions}

Guiso et al. (2013) document that the public views mortgage default as generally immoral. We extend their analysis by delving deeper into the analysis to examine if there are additional intervening factors that further explain the moral viewpoints of others. In the current investigation, we consider the role of both financial outcome and default intent in gaining a deeper understanding of this complex issue. We find that the public is significantly more accepting of a defaulter who ends in a loss or break-even position (i.e., who earns a negative or zero return on his home investment, respectively) than a borrower who defaults and earns a positive return on his investment (ending in a gains position).

Concerning default intent, strategic defaulters are consistently and significantly viewed as having acted less morally when compared to a non-strategic defaulter, who by definition had no choice but to default on his mortgage due to a liquidity constraint. When respondents were asked to suggest a "morally appropriate" settlement offer to satisfy the loan with the lender, both the financial outcome and default intent remained significant intervening effects.

In additional to the two main treatment effects, those who more so blame the lender as opposed to borrowers for the current financial crisis viewed mortgage default as less immoral as did those who had strategically defaulted in the past, and males. When explaining "morally appropriate" settlement offers suggested by the public, we find that those who more so blame the lender, those who view their home as more of an investment, those who have previously strategically defaulted, minorities, and those with lower incomes suggest significantly lower settlement offers.

\section{References}

Ackert, L., Church, B., Jayaraman, N., 2011. Is there a link between money illusion and homeowners' expectations of housing prices? Real Estate Econ. 39 (2), 251-275.

Blount, S., 1995. When social outcomes aren't fair: the effect of causal attributions on preferences. Organ. Behav. Hum. Decis. Process. 63 (2), 131-144.

\footnotetext{
14 When including separate dummies for past default and past strategic default, results remain significant with the expected sign.
} 
Cooper, D., Kagel, J., 2013. Other-regarding preferences: a selective survey of experimental results. In: Kagel, J., Roth, A. (Eds.), Handbook of Experimental Economics. Princeton University Press, Princeton.

Engelberg, J., Parsons, C., 2016. Worrying About the Stock Market: Evidence from Hospital Admissions. Working Paper. University of California at San Diego.

Fannie Mae, 2010, National Housing Survey. http://info.fanniemae.com/ portal/researchand- analysis/2010q4-housingsurvey.html

FICO, 2011, Predicting Strategic Default. White Paper, FICO. April.

Gangel, M., Seiler, M., Collins, A., 2013. Exploring the foreclosure contagion effect using agent-based modeling. J. Real Estate Financ. Econ. 46 (2), 339-354.

Guiso, L., Sapienza, P., Zingales, L., 2013. The determinants of attitudes towards strategic default on mortgages. J. Financ. 68 (4), 14731515.

Harding, J., Rosenblatt, E., Yao, V., 2009. The contagion effect of foreclosed properties. J. Urban Econ. 66 (3), 164-178.

Immergluck, D., Smith, G., 2006. The external costs of foreclosure: the impact of single-family mortgage foreclosures on property values. Hous. Policy Debate 17 (1), 57-79.

Lin, Z., Rosenblatt, E., Yao, V., 2009. Spillover effects of foreclosures on neighborhood property values. J. Estate Financ. Econ. 38 (4), 387407.

RealtyTrac, 2014. U.S. Home Equity \& Underwater Report. RealtyTrac.

Rogers, W., Winter, W., 2009. The impact of foreclosures on neighboring housing sales. J. Real Estate Res. 31 (4), 455-479.
Seiler, M., 2014a. Understanding the far reaching societal impact of strategic mortgage default. J. Real Estate Lit. 22 (2), 205-214.

Seiler, M., 2014b. The effect of perceived lender characteristics and market conditions on strategic mortgage defaults. J. Estate Financ. Econ. 48 (2), 256-270.

Seiler, M., 2014c. Understanding the prevalence and implications of homeowner money illusion. J. Behav. Exp. Financ. 1 (1), 74-84.

Seiler, M., 2015a. The role of informational uncertainty in the decision to strategically default. J. Hous. Econ. 27 (March), 49-59.

Seiler, M., 2015b. Do as I say, not as I do: the role of advice versus actions in the decision to strategically default. J. Real Estate Res. 37 (2), 191-215.

Seiler, M., 2016a, "Determinants of the strategic mortgage default cumulative distribution function," J. Real Estate Lit., (forthcoming).

Seiler, M., 2016b. Do liquidated damages clauses affect strategic mortgage default morality? A test of the disjunctive thesis. Real Estate Econom. (forthcoming) doi:10.1111/reec.12142.

Seiler, M., Collins, A., Fefferman, N., 2013. Strategic mortgage default in the context of a social network. J. Real Estate Res. 35 (4), 445-475.

Seiler, M., Seiler, V., Lane, M., Harrison, D., 2012. Fear, shame, and guilt: economic and behavioral motivations for strategic default. Real Estate Econ. 40 (S1), 199-233.

Wheaton, W., Nechayev, G., Seiler, M., 2015. Rebalancing the U.S. housing market: two proposals. Real Estate Financ. 32 (3), 83-85.

Wyman, O., 2010, “Understanding Strategic Default in Mortgages. Experian Report. 